\title{
REGIMES DE INDIANIDADE, TUTELA COERCITIVA E ESTADANIA: EXAMINANDO A VIOLÊNCIA INSTITUCIONAL CONTRA INDÍGENAS NO BRASIL E NO CANADÁ ${ }^{1}$
}

\author{
CRISTHIAN TEÓFILO DA SILVA ${ }^{2}$
}

$U n B$

\begin{abstract}
RESUMO: $O$ propósito deste artigo é comparar o modo como distintos regimes tutelares de indianidade orientam a ação indigenista no Brasil e no Canadá com efeitos violentos para os indigenas. Os regimes tutelares de indianidade se configuram nestes países para proporcionar a assimilação dos povos indígenas à ordem nacional. $O$ artigo abordará a importância dos regimes de indianidade para a rotinização da dominação interétnica nestes dois países. Dois casos de assistência médica a famílias indígenas em contextos tutelares servirão como eventos críticos para elucidar os estereótipos associados às categorias jurídicas "indio/Indian" e que legitimam a violência institucional contra membros dos povos indígenas sob paradigmas assimilacionistas. A análise comparativa permitirá reconhecer e examinar o alcance e a profundidade das políticas de integração para criar um status inferior de cidadania, que será melhor definida como uma "estadania". Com base na comparação, se justificará a necessidade urgente de superar a subordinação classificatória dos indígenas como seres culturalmente inferiores às sociedades nacionais como condição de possibilidade para promover uma verdadeira cidadania multicultural baseada nos princípios dos direitos humanos.
\end{abstract}

PALAVRAS-CHAVE: regime tutelar; indianidade; violência institucional; estudos comparados.

ABSTRACT: The purpose of this article is to compare how different wardship regimes of indigeneity guide the ethnic action in Brazil and Canada with violent effects for Indigenous Peoples. The wardship regimes of indigeneity are configured in these countries in order to promote the assimilation of Indigenous Peoples to the national order. The paper will address the importance of the regimeso $f$ indigeneity for the routinization of interethnic domination in these two countries. Two cases of medical care for indigenous families in tutelary contexts will serve as critical events to elucidate the stereotypes associated with the legal categories of "indio/Indian" and legitimizes institutional violence against members of Indigenous Peoples under the assimilationist paradigm. The comparative analysis will recognize and examine the

\footnotetext{
${ }^{1}$ Versão em português do texto elaborado para a coletânea Pueblos indígenas y Estado: avances, límites y desafíos del reconocimiento indígena, coordenada por Oscar Mejía Mesa (Université Laval/CRIDAQ) e Pedro Garzón López (Universidad Carlos III de Madrid).

${ }^{2}$ Antropólogo e professor do Centro de Pesquisa e Pós-Graduação sobre as Américas (CEPPAC) da Universidade de Brasília (UnB). Pesquisador Associado do Centre interuniversitaire d'études et de recherches autochtones (CIÉRA) da Université Laval. Sócio Efetivo da Associação Brasileira de Antropologia (ABA) e da Canadian Anthropology Society/La Société Canadienne d'Anthropologie (CASCA). Fundador e coordenador do Laboratório de Estudos e Pesquisas em Movimentos Indígenas, Políticas Indigenistas e Indigenismo (LAEPI) e do Observatório dos Direitos e Políticas Indigenistas (OBIND). E-mail: silvact@unb.br .
} 
scope and depth of integration policies to create a lower status of citizenship that will be better defined as a "statezenship". Based on this comparison the paper intends to justify the urgent need to overcome the subordination of Indigenous Peoples as culturally inferior to national societies. This is a condition of possibility to promote genuine multicultural citizenship based on the principles of human rights.

KEYWORDS: wardship regime; indigeneity; institutional violence; comparative studies.

\section{O predicamento da indianidade}

Este trabalho visa comparar a operacionalização da categoria "índio" para orientar a ação tutelar em diferentes contextos nacionais com o objetivo de reconhecer a violência institucional praticada contra indígenas em decorrência dos estereótipos associados ao termo. Os modos como esta categoria tem sido construída sob um paradigma assimilacionista, que visava resolver o "problema indígena" (DYCK, 1996 [1991]) a partir de políticas de territorialização e assistência paternalista direta, podem ser apreendidos pelos conjuntos de ações indigenistas implementadas em termos práticos e que acabaram por violentar a dignidade das pessoas e famílias definidas categoricamente pelo termo, prejudicando sobremaneira seu reconhecimento como sujeitos de direito e seu tratamento respeitoso.

A definição jurídica do status indígena imposta pelos Estados nacionais possibilitaram as condições para que o "índio" deixasse de ser pensado em termos de "anterioridade", o que Ihe negava "coetaneidade" (FABIAN, 1983) com as sociedades modernas, para ser pensado e tratado como "transitoriedade" para a civilização secular e industrial. A noção de transitoriedade abriu caminho para um ciclo de políticas tutelares específicas para os povos indígenas no continente americano com o propósito de promover sua integração às sociedades nacionais. Este horizonte indigenista assimilacionista, precoce em países da América do Norte, alcançou escala continental com a criação oficial do Instituto Indigenista Interamericano (InInIn) em Patzcuaro, México, no dia 24 de fevereiro de 1940. O InInIn foi a principal agência disseminadora de ideias integracionistas para solucionar o "problema 
indígena" em diferentes países do continente (BLANCHETTE, 2013), e esta "solução" foi apoiada e promovida por diferentes antropólogos com atuação no Estado, que teorizavam sobre mudança social e cultural e denunciavam as condições assimétricas do contato interétnico e exploração econômica entre povos indígenas e frentes de expansão capitalista em distintos países. É a dimensão continental alcançada pelo indigenismo assimilacionista no século XX que possibilita abordar comparativamente os efeitos de poder de suas múltiplas variações nacionais sobre os povos indígenas.

A despeito de sua clara intenção vanguardista, o indigenismo assimilacionista articulava-se a partir de um quadro ideológico positivista, conformado como paradigma cientificista no final do século XIX (TEÓFILO DA SILVA e LORENZONI, 2014), e que conferia inteligibilidade e racionalidade para o exercício indigenista do biopoder (FOUCAULT, 1995) ${ }^{3}$, classificando e hierarquizando a diversidade das culturas e povos indígenas segundo termos e objetivos convenientes aos Estados nacionais em formação. Estes termos e objetivos, por sua vez, foram expressos em conjuntos variados de definições, regras, normas, leis, ações, práticas, programas e políticas com o intuito de definir e classificar os limites da condição ou do status indígena, disciplinarizando suas vidas a partir dessas definições e classificações para, finalmente, viabilizar sua integração às sociedades nacionais como indivíduos ou grupos "civilizados" ou "integrados".

Neste trabalho, refiro-me a estes conjuntos jurídico-políticos definidores da condição ou status indígena com vistas à sua integração às sociedades nacionais pela noção de regimes de indianidade. Tais regimes constituem-se como predicamentos da indianidade ecoando as arregimentações dos aldeamentos missionários e seculares que culminaram em muitas reservas indígenas e tratados, com consequências muitas vezes trágicas e duradouras para os povos indígenas, suas culturas e identidades 4 .

\footnotetext{
${ }^{3}$ Foucault define o biopoder como uma tecnologia política de administração das populações e coisas pelo Estado, de modo a viabilizar a transformação dos corpos e sua disciplinarização segundo categorias de gestão. O emprego deste conceito para pensar os efeitos da administração pública indigenista sobre povos, pessoas e corpos já vem sendo realizado ampla e sistematicamente na antropologia feita no Brasil, sobretudo a partir dos trabalhos realizados ou coordenados por Souza Lima (1995 e 2002).

${ }^{4}$ A primeira apresentação que fiz da noção foi em Teófilo da Silva (2012), quando relacionei de modo mais preciso os regimes de indianidade às formas oficiais de classificação das sociedades indígenas pelos
} 
Pretendo que esta noção se mostre mediadora em termos comparativos das experiências indígenas com a tutela indigenista, uma vez que as diferenças entre estes dois países em sua relação com os povos indígenas e seus territórios mostram-se, de início, mais nítidas do que as semelhanças, a começar pelas próprias definições de "índio/Indian". Para viabilizar a comparação, faz-se necessário recuperar as recomendações metodológicas de Marcel Mauss, para quem a construção de homologias profundas com vistas ao alargamento conceitual constitui o horizonte final das abordagens comparativas (ver MAUSS, 1979 [1902]; TEÓFILO DA SILVA e HÉBERT, 2014). Nesse sentido, analisando mais além das diferenças aparentes, encontraremos nos regimes tutelares de indianidade brasileiro e canadense um modo semelhante de legitimar a dominação interétnica a partir da violência simbólica das classificações. Este aspecto transparece nos conceitos de tutela coercitiva, elaborado por Noel Dyck para o contexto canadense valendo-se dos estudos de Robert Paine no Ártico (DYCK, 1991 e 1997), e poder tutelar, elaborado por Antonio Carlos de Souza Lima para o Brasil (SOUZA LIMA, 1985, 1987 e 1995).

Segundo a definição de Dyck:

(...) the administration of Indian affairs by the Canadian state has embodied a form of coercive tutelage designed to effect the social, economic and cultural transformation of aboriginal peoples and their communities. The ultimate objective of state policy was ostensibly to rid Indians of their Indianness and integrate them and their lands into Canadian society. Operating upon the premise that aboriginal peoples did not know what was in their own best interests, federal officials sought to regulate almost every aspect of Indians' lives, from the rearing of children to the management of material resources (DYCK, 1997, p. 336).

Estados nacionais. Na ocasião, visava-se o estabelecimento de uma noção viabilizadora da comparação das relações interétnicas entre povos indígenas e Estados nacionais em contextos latino-americanos. Em artigo publicado em 2015, apresentei nova forma de operacionalização desta noção, dessa vez aplicando-a aos processos de territorialização brasileiro e canadense, que culminaram na formação de "reservas" como espaços circunscritos de arregimentação da indianidade (TEÓFILO DA SILVA, 2015). Dessa vez, busco exemplificar a noção para lidar com episódios de rotinização tutelar da indianidade em "reservas", em particular no que tange ao "atendimento à saúde", como será proposto a seguir. 
No mesmo sentido, Souza Lima reconhece, para o contexto nacional brasileiro, o exercício do poder tutelar sobre povos indígenas e seus territórios como uma tentativa de monopolizar o governo dos indígenas e seus recursos ao mesmo tempo que operacionaliza uma concepção de comunidade nacional homogênea e indivisa. Para tanto, a formulação de políticas, jurídica ou racionalmente embasadas, acerca das populações indígenas articulada por uma rede administrativa é visada com o intuito de pôr em prática a colonização neobrasileira e a sedentarização dos indígenas, o que implica a redefinição dos povos segundo os termos nacionalizadores.

Ambos os autores reconhecem o fato de que tais práticas de poder não se exercem livre de resistência e antagonismo com os povos indígenas. Nesse sentido, vários trabalhos inspirados por estas concepções têm se concentrado nas relações de resistência e acomodação dos indígenas face à tutela coercitiva/poder tutelar ${ }^{5}$. Entretanto, tem escapado à análise antropológica interpretar como o poder tutelar é operacionalizado na prática, isto é, como exercer o poder em contexto interculturais onde os sentidos e as crenças necessários à legitimação da tutela como regime de dominação interétnica não estão previamente disponíveis, precisando ser impostos autoritariamente.

É com esta preocupação que aciono a noção de regimes de indianidade, com o objetivo de redirecionar a perspectiva antropológica sobre os indígenas para o exame dos estados, agora com "e" minúsculo, como propõe Tanaka (2008), justamente para lidar com processos de imposição da dominação racional burocrática classicamente tipificada por Max Weber e sua responsabilidade na definição da situação histórica desvantajosa em que se encontram a maioria, senão todos, os povos indígenas, recuperando, em tempo, a formulação de Guillermo Bonfil Batalla (1981, p. 103), para quem: “(...) a antropologia, ainda que estritamente ocupada com o índio, não possa evitar a análise crítica da sociedade dominante".

\footnotetext{
${ }^{5}$ Para uma análise sobre o sistema tutelar e as resistências locais promovidas pelos indígenas, ver o artigo de Vitenti (2008), o qual tem a vantagem de constituir-se como uma intepretação para o francês canadense das contribuições de Souza Lima sobre o poder tutelar no Brasil.
} 
É com o objetivo de analisar criticamente sociedades dominantes e os constrangimentos que estas impõem para a efetivação da cidadania dos povos indígenas que abordarei episódios de constrangimento e violência cotidianos vividos por indígenas sob a tutela dos brancos. Serão descritos dois casos de atenção médica a indígenas nos quais se pode dimensionar o poder da tutela coercitiva para orientar e justificar a violência física e simbólica com relação aos indígenas. Como se espera demonstrar, este enquadramento tutelar da ação indigenista somente se faz possível porque aos indígenas não é concedida uma verdadeira cidadania, mas uma "estadania", entendida como uma imposição de um padrão de comportamento e participação social de "cima para baixo", ou do Estado para a sociedade, e não o inverso6.

O que se pretende não é repercutir a exposição do sofrimento indígena sob tutela, mas refletir sobre as condições que o tornaram possível. E isto será feito com vistas a obter os elementos para sua efetiva reversão. Nesse sentido, parto de dois eventos críticos extraídos de etnografias realizadas no Canadá e no Brasil. Estes eventos mostram-se críticos (ainda que não o sejam em escala nacional, como o conceito de "eventos críticos" faz supor - Cf. DAS, 1995) do biopoder exercido sobre os indígenas nestes dois países. A utilização deste material visa afirmar a relevância de se fazer uma sociologia comparada das formas de dominação interétnica exercidas pelas sociedades nacionais sobre povos indígenas tornados objetos de poder pela tutela indigenista.

Bem compreendida, a análise a seguir visa contribuir tanto para o urgente exercício da imaginação antropológica em prol da superação do sofrimento como efeito do exercício da tutela indigenista, quanto para a promoção de ações práticas de engajamento político e crítica cultural (HALE, 2006) contra a reprodução estereotípica de definições de "índio" como sociedades e culturas em transição na ordem nacional e internacional.

\footnotetext{
${ }^{6}$ Ainda que este trabalho se inspire na concepção de "estadania" elaborada pelo historiador brasileiro José Murilo de Carvalho (CARVALHO, 1996 e 2007), não se emprega o conceito aqui no mesmo sentido e com a mesma finalidade pretendida pelo historiador, que buscou interpretar a construção da "cidadania" no Brasil em diálogo com a teoria de T. H. Marshall (1967 [1950]), de modo a particularizar a trajetória brasileira de construção da cidadania. A ideia aqui é simplesmente reter o caráter vertical e assimétrico pelo qual os Estados impõem uma concepção de "cidadania" para os povos indígenas com vistas a assegurar sua "inclusão" nos serviços e políticas da sociedade nacional.
} 


\section{Integração, tutela e regimes de indianidade em perspectiva comparada}

Para melhor contextualizar as circunstâncias que propiciaram os eventos a serem analisados, deve-se ter em mente que os processos de arregimentação de povos indígenas no Canadá e no Brasil possuem uma temporalidade multissecular. Tendo como ponto de partida a experiência missionária católica no Canadá, a primeira missão para catequizar e sedentarizar os Algonquinos se deu no início do século XVII, no local designado como Sillery, situado hoje na cidade do Québec. No Brasil, ainda que existam experiências missionárias católicas no século XVI, as reduções ou aldeamentos ganharam sistematicidade somente no século XVII, entrando em declínio no final do século XVIII. Estas missões constituem a arqueologia física e simbólica das reservas e terras indígenas contemporâneas, assim como do quadro mental através do qual se elaboraram as políticas indigenistas no século XX (SIMARD, 2003).

No Alto Canadá, as reservas indígenas foram estabelecidas como política em 1830, com o relatório do major-general Darling, superintendente de assuntos indígenas, segundo o qual, conforme registrado por Upton:

Indians should be collected into villages with only enough land for their agricultural support. The government should provide for their religious instruction, elementary education, and training in agriculture. It should encourage them to build houses and acquire tools and seed. But it would be expensive (...) to settle a family of five on cleared land and (more expensive) on forest land. Therefore the Indians should pay the cost of their own assimilation by using the moneys from land sales to buy the necessary equipment. Further changes in the Indian's way of life could be encouraged by varying the nature of the presents substituting, for example, ready-made trousers and shirts for blankets (UPTON, 1973, p. 57).

Nesse sentido, como observaram Lavoie e Vaugeois (2010, p. 27): "Le projet de civilisation proposé par Darling reposait sur l'idée qu'il 
fallait assister matériellement les Indiens pour faciliter leur transition de la vie sauvage à la vie civilisée".

Uma vez estabelecida a orientação assimilacionista, em 1876 se promulgou o Indian $A c t$, o qual constitui o primeiro direcionamento jurídico das relações do Estado canadense com os "bandos" das Primeiras Nações e seus membros e também com a administração das reservas indígenas. Ainda que tenha sofrido dezenas de alterações, o Indian Act governou dois temas principais:

1) Ele determinou como as reservas e os bandos poderiam funcionar, limitando os poderes dos "conselhos de bandos";

2) Ele definiu quem poderia e quem não poderia ser reconhecido como "Índio". O Ato define quem pode ser "registrado", e, assim, ter "status" de indígena, e aqueles que não poderão ser considerados membros do "bando".

O segundo aspecto do Indian Act se provou particularmente controverso e sexista ao estabelecer que mulheres casadas com maridos sem status ou não indígenas perderiam o status de indígenas, assim como seus filhos.

No caso brasileiro, para nos limitarmos ao indigenismo republicano, conta-se mais de 100 anos desde a criação, em 1910, do Serviço de Proteção aos Índios e Localização de Trabalhadores Nacionais (SPILTN), depois renomeado apenas de Serviço de Proteção aos Índios (SPI). Este órgão foi responsável pela implementação das primeiras medidas de localização e integração de comunidades e povos indígenas a partir de uma correspondente integração territorial a partir de linhas telegráficas (DIACON, 2004).

Deve-se ter em mente que os debates indigenistas da primeira república, herança do império, se davam no âmbito do Instituto Histórico e Geográfico Brasileiro (IHGB) com base em duas opções: o extermínio dos índios ou a sua assimilação à sociedade nacional. A opção por uma política assimilacionista através da incorporação dos indígenas ao "exército de reserva" da força de trabalho nacional foi a 
principal doutrina praticada em acordo com o ideário do positivismo comteano que vigorava no meio militar e intelectual da época.

$O$ indigenismo positivista firmava-se a partir de uma diretriz ambivalente: proteger os índios e assegurar a expansão nacional sobre seus territórios. As ações do SPI tinham sua base legal definida pelo Código Civil de 1916 (Lei 3.071/1916 promulgada com base em um projeto de 1889). O SPI foi substituído pela Fundação Nacional do Índio (Funai) através da Lei 5.371/1967, que, finalmente, vem pautando suas ações e políticas com base no Estatuto do Índio (Lei 6.001/1973), ainda em vigor, e que visa "preservar as culturas indígenas" e promover sua "integração harmoniosa" à sociedade nacional. Para isto, serve-se da definição jurídica do "índio" como ser "relativamente incapaz" e sujeito à tutela pelo Estado. Portanto, pode-se dizer que o Estatuto do Índio, promulgado durante um regime ditatorial militar, tem, para o Brasil, o mesmo peso e importância que teve o Indian Act para o Canadá, com todas as suas implicações totalitárias para a vida dos povos indígenas: o (não) reconhecimento dos seus direitos originários e a gestão dos seus territórios e projetos de vida.

A reorientação e redefinição das políticas assimilacionistas canadense e brasileira ocorreu somente com a mobilização política indígena nos anos 60 e 70 do século XX. No Canadá, a luta política indígena se intensificou com as tentativas do governo de promover arbitrariamente a "emancipação civil" da condição tutelada dos indígenas com a proposta do White Paper (WEAVER, 1981), o qual foi duramente criticado pelos indígenas e suas lideranças. Para a rejeição integral da proposta, também colaboraram relatórios administrativos elaborados por antropólogos e sociólogos que revelaram detalhadamente as más condições de vida nas reservas, além das múltiplas complicações e processos judiciais decorrentes da legislação indigenista vigente. Com o processo de repatriação da Constituição do Canadá, os direitos territoriais e tratados feitos com os chamados "Indians", "Inuit" e "Métis" foram mais uma vez reconhecidos e reafirmados na Seção 35 do Constitution Act de 1982.

No Brasil, a luta indígena também foi impulsionada pelo interesse do governo militar em "emancipar" legalmente os indígenas da tutela com vistas a torná-los cidadãos iguais aos demais membros da 
sociedade brasileira e, assim, tornar seus territórios passíveis de negociação individual (RAMOS, 1998). A reação indígena contou com o apoio da sociedade civil contra o regime militar, quando diversas organizações e movimentos sociais colaboraram, já em meados dos anos 80 , para promover a transição democrática e promulgar a Constituição de 1988. Nesta, se assegurou amplos direitos sociais e políticos e também direitos coletivos e territoriais para os povos indígenas. Estes foram explicitamente descritos no artigo 231 da Constituição federal, onde lê-se: "São reconhecidos aos índios sua organização social, costumes, línguas, crenças e tradições, e os direitos originários sobre as terras que tradicionalmente ocupam, competindo à União demarcá-las, proteger e fazer respeitar todos os seus bens".

As configurações constitucionais nos dois países inauguraram a transição ideológica do paradigma assimilacionista para o multiculturalista, de modo que práticas e concepções tutelares ou paternalistas fossem superadas em prol da promoção da autodeterminação, do autogoverno e do pluralismo jurídico entre os povos indígenas em suas reservas e territórios. Como os dois episódios descritos a seguir ocorreram em um momento no qual este novo regime de indianidade ainda não havia sido implementado, redescrevê-los, nesse momento, serve para elucidar a extensão e profundidade do assimilacionismo para traumatizar comunidades e pessoas indígenas a partir das concepções e práticas tidas como tutelares.

Colocados nestes termos, os casos nos permitem refletir sobre o caráter biopolítico do regime tutelar de indianidade, obrigando-nos a questionar até que ponto, ou em que ponto exatamente, o novo horizonte multiculturalista deverá redistribuir o poder e reverter o paternalismo tutelar, também claramente expresso na experiência das escolas residenciais no Canadá e das "escolas para índios" no Brasil, de modo a promover a necessária retratação, reparação e cura pela tutela coercitiva como a principal violência a ser superada.

O primeiro caso a ser recuperado foi extensamente analisado por Dara Culhane em seu livro An Error in Judgement: The Politics of Medical Care in an Indian/White Community (1987), no qual a morte de uma jovem nimpkish sob cuidados médicos causou a indignação da comunidade. O segundo advém de minha própria pesquisa entre os 
Avá-Canoeiro e está publicado no livro Cativando Maíra: A sobrevivência dos índios Avá-Canoeiro no Alto Rio Tocantins (2010), no qual reproduzo o relato do nascimento de Trumak, em fevereiro de 1987. A seleção de dois casos que envolvem o entrelaçamento de relações tutelares e práticas de atenção à saúde visa justamente evidenciar a gramática da tutela coercitiva/poder tutelar estabelecida duplamente pela reclassificação dos Nimpkish e dos Avá-Canoeiro como "índios" seguida de sua manipulação como "pacientes indígenas". Isto é, são casos clínicos reveladores da eficácia do biopoder tutelar para negar a autonomia indígena e fazer morrer fisicamente ou simbolicamente os sujeitos para produzir os "índios/Indians" como corpos passivos para a ação dos Estados nacionais.

\section{A "cultura indígena" como justificativa para a negligência médica e violência institucional entre os Nimpkish}

Segundo Culhane, no dia 22 de janeiro de 1979, uma criança indígena de 11 anos de idade morreu no hospital de Albert Bay (Columbia Britânica) em decorrência de uma crise de apendicite mal diagnosticada. Os protestos da comunidade indígena que sucederam à negligência médica mobilizaram a mídia nacional e se mostraram elucidativos de que por trás de um aparente caso de tragédia pessoal e familiar subsiste um padrão de poder colonialista praticado por missionários, agentes indigenistas, profissionais de saúde e assistentes sociais cujo trabalho foi orientado a trazer e promover entre os indígenas os "benefícios" da sociedade civilizada (JACKSON apud CULHANE, 1987, p. 10).

Para não reproduzir a descrição e análise densa de Culhane, cabe recuperar trechos de sua vívida representação do caso, a qual abre o primeiro capítulo do livro, em busca dos indícios que elucidam o caráter rotinizado da dominação interétnica no regime de indianidade canadense:

1. Alert Bay, B.C.

January 1979

Arthur Dick, Sr. is a successful man by anyone's standards. In 1979 he owned two large seine boats, 
each employing five men fishing salmon and herring off British Columbia's west coast. A member of the Nimpkish Indian Band situated at Alert Bay ${ }^{7}, \mathrm{Mr}$. Dick had served intermittently on the elected Band Council of his reserve community for many years; he had been an active member of the Native Brotherhood of British Columbia, an organization formed in 1931 to lobby for improvements in opportunities for B.C. Indians; and he was a high-ranking chief and host of many lavish and well-attended potlaches. Coming from a big family himself, he had married a woman from a large and prestigious local family and together they had raised seven children: six daughters and a son. [...]

The 1978 salmon season had been lucrative for some of Alert Bay's commercial fishermen, including Arthur Dick, Sr., who was among those who could boast of having been a "highliner" that year. In January of 1979, when his grandchildren had returned to school after the Christmas holidays, Mr. Dick, Mrs. Dick, four of their daughters, two sons-in-law, and his son and daughter-in-law left to spend a week in Reno to celebrate their good fortune and to take a break before herring fishing began in February.

Richard's brother, Leonard, moved into Margaret and Richard's home to take charge of Renee, aged eleven and Richard Jr., aged six and on Thursday, January 11, 1979, an elated entourage left Alert Bay for the bright lights of Reno.

Renee and Richard Jr. both had sniffles and sore throats when Margaret and Richard left and when, by Saturday, their colds appeared to be getting worse, Leonard opted for a "better safe than sorry" strategy and took both children to see Dr. Harold J. "Jack" Pickup, the island's sole medical practitioner. Dr. Pickup prescribed cough medicine and pills to be taken every four hours.

Leonard kept his charges home from school on Monday but by Tuesday their colds had cleared up and they went back to school. On Wednesday Renee complained to Leonard that her stomach hurt and throughout the day she was troubled by vomiting and diarrhea (sic). The medicine prescribed on Saturday was finished so Leonard decided to take her back to the doctor. The doctor is away on Wednesdays and his

\footnotetext{
7 A Reserva Indígena Nimpkish, chamada "a Aldeia", ocupa metade de uma extensão de $8 \mathrm{~km}$ (aproximadamente) de comprimento por $1 \mathrm{~km}$ de largura da Ilha Cormorant, a qual está a meio caminho entre a Ilha de Vancouver e o continente, cercada pelas águas do Estreito de Johnstone. Aproximamente 700 dos 1000 membros do "bando indígena" Nimpkish vivem ali (Nota acrescentada a partir de outros trechos do próprio texto de Culhane aqui citado).
} 
clinic is closed all day so Leonard called the hospital and explained his niece's symptoms to a nurse, telling her that he was especially worried because now she seemed to be having bad stomach pains. The nurse told him to bring her down to the hospital so they could take a look at her.

$[\ldots]$

Renee was having trouble standing up straight and it was so painful for her to move at all that Leonard had to help her out of the cab and support her with is arm as they walked into Sr. George's. At the hospital Renee and her uncle were seen by a young woman who had nursed since 1974 when she completed training in her native Philippines. After having him sign some forms and pay the two-dollar out-patient fee, the nurse asked Leonard to wait outside while she took Renee into a private examining room. She noted Renee's symptoms: nausea, diarrhea (sic) and severe abdominal pain, and asked Renee to lie down so she could examine her. A distraught Renee pushed the nurse's hand away and said she didn't want to be examined. The nurse then called the doctor at his home next door and explained the girl's symptoms. Dr. Pickup told her to admit Renee for observation. The nurse relayed this advice to Renee who responded, crying, "I don't have to stay in your damned hospital! Just give me a pain killer! I'm in pain!" The nurse placed a second call to Dr. Pickup and reported Renee's refusal. Dr. Pickup prescribed 642s (Propoxyphene) for pain and suggested that Leonard be told to bring Renee back the next day if her condition had not improved. The nurse reported this information to Renee, handed her an envelope containing eight Darvon-N capsules and sent her and her uncle on their way.

Despite the medication, Renee's symptoms worsened and the next morning - Thursday, January $18^{\text {th }}$ - Leonard phoned the doctor's office and explained to the receptionist, Mrs. Pickup, that Renee was still throwing up, still in pain and only drinking apple juice. Mrs. Pickup gave him an appointment for 4:30 p.m. that day. When they arrived, Dr. Pickup X-rayed Renee's chest and told Leonard that Renee "had to have an operation right away." Leonard agreed to hospitalization but said he didn't think he could give consent for an operation until he had contacted Renee's vacationing parents.

"I can't wait that long", Dr. Pickup cautioned. Leonard replied that he didn't think he had the legal right to authorize an operation and would try to contact Margaret and Richard immediately. At 5:20 p.m. 
Leonard pushed his niece, in a wheelchair, from the doctor's office to the admitting desk in the adjoining hospital. A nurse hastily completed admitting procedures, copied Dr. Pickup's diagnosis of "acute abdomen" onto a patient chart, noted that Renee appeared "pale, anxious and in considerable pain" and gave Leonard a form to sign, explaining that it was a routine admitting form. Guessing at Renee's weight in order to determine appropriate dosages, the admitting nurse began to administer the four different drugs the doctor had ordered to combat pain, nausea, infection and fever.

After seeing his niece settled in a hospital bed, Leonard returned home to contact Renne's parents and to notify other relatives. Once Renee's conditions was known, female relatives who worked as kitchen help and cleaning women in the hospital checked in on Renee whenever they had a break, while other relatives took turns sitting by her bedside round the clock, comforting her, seeing to her needs, reporting their observations of her condition to the nurses, and questioning the doctor when he arrived to make his rounds. Such vigils are common practice among Alert Bay area Indians when a family member, particularly a child, is hospitalized with a serious ailment.

Leonard reached his brother, Richard, in Reno on Thursday evening, January $18^{\text {th }}$. The entire Dick family group cut their holiday short, rearranged plane reservations as quickly as possible, and returned to Alert Bay on the evening of Friday, January $19^{\text {th }}$. Margaret's sister, Ethel Scow, had taken her annual holiday leave from her job as receptionist at the Indian Health Office to go to Reno with her family. On February 3, 1979, two weeks after Renee was first hospitalized, Ethel wrote a detailed account of the time she had spend with Renee at St. George's, beginning with the family's return to Alert Bay and their arrival at the hospital on Friday night (CULHANE, 1987, p. 23-26, parêntesis adicionados)

A partir deste ponto, Culhane passa a descrever os eventos seguintes citando as anotações de Ethel Scow, do mesmo modo como venho transcrevendo seu relato. Segundo as anotações de Scow, o médico teria dito aos familiares que Renee havia contraído o pior tipo de gripe, a qual afetava as crianças ainda mais, porém, que ela estaria melhorando. No dia seguinte, Scow conversou com a irmã, a quem o médico disse que o problema seria o apêndice, mas que ele achava que 
não precisaria operar porque Renee havia apresentado melhoras consideráveis. Entretanto, Ethel observava que Renee apresentava arritmia, vomitava a medicação e prosseguia com dores. O médico examinava o abdômen de Renee pelo menos duas vezes por dia. A cada vez, ele dizia que ela estava melhorando e que ficava feliz por Renee ter conseguido sentar-se por alguns instantes. Ele então prescreveu remédios contra náusea e assegurou que Renee ficaria bem. A partir da noite e manhã seguinte, o relato de Ethel aponta para a piora no quadro. Fizeram exames de raio $\mathrm{X}$ e recomendaram exercícios, além da troca de camisolas e roupas de cama. Como a náusea e as dores não cessavam, enfermeiros e médicos intensificaram a medicação e reiteravam que Renee ficaria bem.

Na segunda-feira, 22 de janeiro de 1979, Richard relatou a Ethel que Renee passava por dores agudas no estômago durante a noite, ela pedia pela mãe enquanto seu quadro se deteriorava. A enfermeira das Filipinas apareceu com a cadeira de rodas para levar Renee novamente para mais exames de raio $X$. Renee gritava e contraía o estômago. Aparece um técnico de laboratório que aplica medicação intravenosa. Quando perguntado sobre a medicação, a enfermeira filipina respondia, mas não podia ser compreendida por causa do seu sotaque. O médico apareceu por volta das $11 \mathrm{~h}$ e, diante do quadro e dos apelos dos familiares, solicita um enema (também denominado enteroclisma ou clister, consiste na introdução de água no ânus para lavagem intestinal, purgação ou administração de medicamentos através de uma sonda retal). Horas mais tarde, diante do agravamento do quadro, o médico foi contatado, mas não apareceu, apenas recomendou mais medicação intravenosa. Uma hora depois, Richard chama pela enfermeira, que, ao olhar para Renee, aciona o médico, que chega em poucos minutos e grita por oxigênio. Vários tanques de oxigênio são trazidos, todos vazios. Ele tenta ouvir o batimento cardíaco com o estetoscópio e o arremessa ao chão pedindo outro e alegando que aquele não funcionava. Novo tanque de oxigênio chega e a máscara é colocada sobre o rosto da criança. Tarde demais, ela havia falecido.

A família reúne-se em torno da cama. Devastada. Dr. Pickup ordena à enfermeira que providencie barbitúricos (Secobarbital) para os familiares. Quando a enfermeira retorna, ele reclama: "Isso não é 
suficiente! Dê muitos a eles! Garanta que todos recebam muitos!”. Mais tarde, a enfermeira encontra Dr. Pickup sentado no saguão. "Ele estava chorando". "Eu não sabia o que dizer a ele. Ele estava alcoolizado. Ele não estava embriagado. Ele disse apenas que não dormiria aquela noite" (CULHANE, 1987, p. 30-31).

Dois dias depois, o responsável pelo necrotério, Leo O'Connell, chegou em Alert Bay para preparar o corpo para o funeral. Preocupado que o atestado de óbito não apresentava a causa mortis, ele começou o processo de embalsamento. Entretanto, notou tecido cicatrizado em torno da vagina da criança, levantando a suspeita de que ela teria sofrido violência sexual. Sem saber como proceder, ele interrompe o procedimento e decide cuidar do assunto depois do jantar. Ele dirige um pouco pela cidade e retorna ao hospital perguntando à enfermeira se ela sabia algo sobre a morte de Renee Smith.

A enfermeira disse que elas pensavam o mesmo que ele, que quando a garota era paciente lá ... que ela teria sido violentada. Elas disseram que quando a visitavam no quarto para cobri-la com um cobertor ou tocá-la, a garota mencionava o nome de um homem e dizia "não me toque mais, me deixe em paz" (CULHANE, 1987, p. 31-32).

O'Connell então decide falar com Dr. Pickup, a quem encontra novamente embriagado. $O$ médico disse a ele que não havia registrado a causa da morte porque ainda não havia decidido o que escrever. Alegou que não havia pedido autópsia porque os "índios" em geral não gostam que sejam feitas autópsias. A pedido de O'Connell, ambos se dirigem ao necrotério para reexaminar o corpo de Renee. Quando ele a examina, ele se mostra surpreso e diz concordar com O'Connell, porém que não o apoiaria na denúncia, que julgava melhor voltarem a conversar sobre o assunto na casa dele, onde ele tenta convencer O'Connell a manter o assunto em sigilo. Contrariando o médico, O'Connell aciona a polícia e o administrador do hospital. Todos concordam que havia evidência de agressão sexual e que, portanto, uma autópsia fosse conduzida. A família de Renee foi então contatada e informada sobre a autópsia e o abuso sexual. Familiares não compreendiam por que o médico levou dois dias para relatar a morte. 
A autópsia estabeleceu que a morte foi decorrente de uma peritonite decorrente da ruptura do apêndice. O patologista alegou ter feito um exame detalhado nos órgãos sexuais e não encontrou nenhum problema. Como conclusão do relato, Culhane registra:

William Deadman, formerly a local magistrate and administrator of St. George's, and, in 1979, a trustee of the St. George's Hospital Society, husband of the hospital's medical records librarian, close friend and associate of Dr. Pickup's, and local coroner, received the results of the autopsy. He concluded that death was neither unnatural nor accidental, nor, in his opinion, had Renee's death been sudden or unexpected. Under the circumstances, he could see no reason to call an inquest (CULHANE, 1987, p. 33).

O drama acima relatado não deve ser pensado como um incidente excepcional. A comunidade indígena de Alert Bay, segundo relata Culhane, havia atravessado um inverno particularmente ruim em 1978, sequenciado por vários funerais. Três anos antes do caso de Renee Smith, uma de suas tias, Louisa James, deu entrada no hospital St. George para uma histerectomia e morreu em seguida de peritonite após a operação (CULHANE, 1987, p. 37). Ela também era paciente do Dr. Pickup e de um segundo médico. Nem autópsia, nem inquérito foram abertos por Deadman. Perpassando estes e outros casos, o Conselho Distrital Kwakiutl debatia os cortes orçamentários para os serviços médicos. Segundo o chefe Roy Cranmer, do bando Nimpkish: "Os problemas que encaramos aqui até hoje vão muito além das práticas do médico local. Elas pré-datam cem anos, ao modo de pensamento que caracteriza as atitudes não-indígenas com relação ao povo indígena..." (CRANMER, 1980 apud CULHANE, 1987, p. 65). Segundo o manual de estudantes e professores da Associação de Hospitais Canadenses, volume 5,1984 , página 50 , pode-se ter uma ideia sobre o pensamento e atitudes mencionados:

Cultural attitudes to violence differ - Indians do expect to suffer more pain, discomforts, disabilities and deformities because they fight more. There are more accidents and deaths. Infant mortality is high, but the loss of a child in an Indian community is accepted in an 
entirely different frame of mind than in a white man's society [...] (apud CULHANE, 1987, p. 35).

Nota-se, com isso, de que modo o regime de indianidade propicia um quadro mental e prático para a negligência médica como uma prática rotinizada em Alert Bay. A banalização do sofrimento e da morte indígena no âmbito das políticas e atendimentos de saúde são expressão de um efeito colateral esperado de comunidades e pessoas transitando de costumes e culturas na qual a dor, o desconforto e a morte são presumidas como corriqueiras para um contexto no qual os sujeitos seriam tratados de um "modo inteiramente diferente". A justificativa da "cultura indígena" como um álibi para a negligência criminosa preenche os espaços abertos por relações pessoais e solidárias entre uma equipe de "especialistas" e "tutores" não indígenas, responsáveis pela administração e contenção do potencial disruptivo da comunidade indígena, e que terminam impunes por seus atos uma vez que as circunstâncias mencionadas são rotineiras e banais quando se tratam de um "bando de índios".

\section{A proteção contra a extinção como justificativa para a etnogênese dirigida entre os Avá-Canoeiro}

No ano de 1973, seis avá-canoeiro foram contatados na llha do Bananal, na região central brasileira, e destes apenas quatro sobreviveram ao regime tutelar imposto após o contato forçado. Atualmente, os sobreviventes e seus descendentes vivem em aldeias do povo Javaé sob a assistência precária da Fundação Nacional do Índio (Funai) enquanto aguardam a regularização fundiária de suas terras tradicionais (RODRIGUES, 2013). Dez anos depois, em 1983, no alto Rio Tocantins (também designado Maranhão), quatro avá-canoeiro entraram em contato com moradores regionais. Eram três mulheres: Matxa (44 anos, idade aproximada em 1983), Nakwatxa (39) e Tuia (14). E um homem: lawi (24), a quem os tutores atribuíram a liderança e o nome do grupo.

Os Avá-Canoeiro eram procurados por sucessivas "frentes de atração" do órgão indigenista, como eram designadas as equipes que 
tinham por objetivo localizar, atrair e fixar em locais específicos povos, famílias e indivíduos indígenas que viviam dispersos por conflitos e epidemias provocadas pela expansão socioeconômica da sociedade brasileira ou em relativa autonomia em áreas florestais remotas dos centros urbanizados. Diferente dos Avá-Canoeiro contatados na llha do Bananal, os quais foram obrigados a viver na periferia das aldeias javaé, os Avá-Canoeiro do alto Rio Tocantins foram fixados no interior de um território de 38 mil hectares, onde passaram a receber proteção tutelar do Estado brasileiro enquanto outras frentes de atração tentavam localizar outros grupos dispersos.

A complexidade do caso resulta da impossibilidade de os AváCanoeiro reproduzirem seu modo próprio de vida coletiva, uma vez que sua sociedade foi totalmente destruída ao longo de mais de 300 anos de contato com frentes colonizadoras de garimpo, criação de gado e projetos de desenvolvimento, como a construção de uma barragem para aproveitamento hidrelétrico do Rio Tocantins (TEÓFILO DA SILVA, 2010). Dito de outro modo, os Avá-Canoeiro foram privados do convívio com os demais membros de sua sociedade em decorrência de massacres, perseguições e precárias condições de sobrevivência, sendo posteriormente inseridos em um regime de proteção e assistência que visava "salvar os Avá-Canoeiro da extinção".

Trata-se de uma situação completamente distinta e distante da anteriormente vista em Alert Bay, exceto pelas práticas tutelares paternalistas acionadas em ambos casos, apoiadas que estão em definições prévias sobre o "índio". No caso avá-canoeiro, entretanto, o enfoque que deve ser dado ao caso aponta para a exacerbação das preocupações e das ações indigenistas em face de um segmento atomizado de um povo concebido analogamente a outras espécies animais como "uma etnia em vias de extinção", o que nos permite avaliar até que ponto o poder que se exerce sobre os Avá-Canoeiro atravessa e transforma não só o corpo fragmentado de suas representações e práticas culturais, mas também seus próprios corpos e atitudes individuais.

Nesse sentido, as ações indigenistas implementadas na Terra Indígena expressam a outra face das políticas assimilacionistas, uma vez que visam proteger ao máximo os sobreviventes de extermínio do 
contato com a sociedade regional e nacional, percebido como prejudicial para os indígenas, para implementar medidas que visam a reconstituição da sociedade indígena pela reprodução física dos índios. Paradoxalmente, as condições em torno do nascimento da primeira criança avá-canoeiro sob tutela no alto Rio Tocantins expressam o teor das preocupações tutelares no sentido de assegurar a sobrevivência de indivíduos avá-canoeiro para reconstruir sua sociedade com vistas a promover, posteriormente, sua integração.

O principal registro disponível sobre o nascimento de Trumak (renomeado Jatulika ao deixar a infância), seguido pelo nascimento de Putdjawa (renomeada Niwatima pelas mesmas razões do irmão), encontra-se no relatório de autoria de Mário Arruda Costa, de janeiro de 1992. A extensa narração de Costa, reproduzida parcialmente a seguir, transmite o espírito indigenista da época, seja pelas referências às intenções e práticas de funcionários e pesquisadores diante da "reprodução" dos Avá-Canoeiro, seja pelo modo de garantir sua "sobrevivência" e "saúde":

Conhecendo o costume de alguns povos indígenas, que param de procriar, a partir do momento do primeiro contato com a nossa civilização, ou quando transferidos de suas terras $[\ldots]$, não só ficamos atentos, mas tomamos algumas providências, no sentido de ver o grupo Iawí procriando o mais cedo possível, a partir do primeiro contato. [...] Instalados no córrego dos Macacos fizemos todos os esforços com o chefe do posto Canguçu na formação de lavouras de mandioca, cana, arroz, banana, feijão, milho, abóbora, melancia e mais criação de galinhas e porcos. Assim imaginamos tranqüilizar os índios diante de tanta fartura própria deles, pois o posto da FUNAI nem sempre estava bem sortido de alimentos para os índios.

As constantes mudanças de chefe de posto, promovida pela FUNAI, nos deixava preocupados, pois os índios reagiam negativamente a cada momento que chegava um novo chefe. Notamos, contudo, que a permanência constante do auxiliar de posto Sinval gerava confiança nos índios, deixando-os mais tranqüilos, face às mudanças. Por isso, resolvemos trabalhar com Sinval, no intuito de convencer as índias a gerar filhos. Para tal, fizemos várias viagens ao Posto Canoeiro, acompanhado da bolsista do CNPq Martha 
Maria de Oliveira e da menina Mayara Arruda de Oliveira, incentivando as índias a ter filhos.

Em novembro de 1985, Sinval nos informava (por telefone), que a índia Tuia sofreu um aborto. Era uma notícia triste, porém promissora. Sabíamos agora que Tuia era capaz de conceber. O próximo passo era descobrir a causa ou causas do aborto. Partimos para o posto, onde encontramos a Tuia muito abatida [...].

Em junho deste ano, recebemos o telefonema de Sinval nos avisando que Tuia estava grávida, com parto previsto para o final de março ou começo de abril de 1987. Retornamos ao posto no dia 23 de fevereiro de 1987, com a intenção de estudar o ritual de nascimento entre os Avá-Canoeiro para, além de chegar a tal conhecimento, receber a criança num mundo anteriormente Canoeiro. Para surpresa e espanto nosso, Tuia já tinha dado a luz a um menino. O parto foi no mato, a oeste da casa. [...] Quando os funcionários da FUNAI, Benoni e sua esposa, e o auxiliar Sinval chegaram, Matcha já tinha saído do mato com a criança, seguida tranqüilamente por Tuia. Matcha mostrou a criança ao Iawí, que a examinou com surpresa, chamando-a de Mitcheã. Tudo era tranqüilidade entre os índios, mas Benoni e sua esposa, tendo sido pegos de surpresa pelo nascimento imprevisto, talvez prematuro, precipitadamente embrulharam a criança numa coberta, pegaram Tuia e Iawí e correram para o barco. Chegando ao canteiro de obras de FURNAS, receberam um carro à disposição que os conduziu à Minaçu e de lá à Goiânia. Este processo, certamente, violentou todos os costumes dos Avá, o que deixou Matcha e Naquatcha revoltadas, a tal ponto que se recusaram a nos receber. Retornamos a Goiânia imediatamente, onde encontramos os três canoeiros na Casa do Índio. Na época, a bolsista do CNPq Martha Maria de Oliveira, escreveu o seguinte, em seus relatórios:

'Chegando a Goiânia, na noite do dia 26/02/87, nos dirigimos para a Casa do Índio as 08:00 h. do dia seguinte, onde encontramos Iawí, Tuia e o recémnascido. A primeira vista, a criança nos pareceu saudável. Tuia muito abatida e Iawí muito nervoso, não entendiam porque estavam ali. [...]

Ao retornar, o prof. Mário tomou conhecimento da implicância que uma enfermeira fez comigo (Martha) para que eu não levasse mais os índios Canoeiro para nossa casa. Por causa disso, na terça de carnaval, eu não busquei os três índios na Casa do Índio. À tarde eles saíram da Casa do Índio e se refugiaram num lote vago, ali perto. Os três dormiram ali, sob pesada 
chuva, durante toda noite. Pela manhã, quando retornaram para Casa do Índio, o recém-nascido estava com indício de pneumonia. O menino foi internado no IGOP (Instituto Goiano de Pediatria). A partir daí, acionamos os Drs. Murilo e Eliane para acompanhar de perto o menino internado, o que foi feito com muita competência.'

Novamente voltamos a assistir Iawí e Tuia até o final da semana das cinzas, quando Benoni levou os dois de volta, sem nem mesmo passar, em casa, para pegar as roupas do Iawí e Tuia, que estavam secando no varal. Os dois partiram, mas o recém-nascido ficou internado até o dia 28/03/87, quando saiu do hospital e passou a morar com o médico da FUNAI, até final de maio, quando foi devolvido a seus pais, no córrego dos Macacos, acompanhado de uma antropóloga [...] e uma enfermeira da FUNAI. A criança foi bem recebida e adaptou-se perfeitamente. Após o retorno do pequeno ao posto indígena, a sua avó Matcha deu a ele o nome de Trumach $[\ldots]$.

O pequeno Trumach sofreu ainda várias crises de pneumonia e teve que ser reconduzido ao posto indígena, debaixo dos mais variados climas de apreensão, sem sabermos ao certo, o que aconteceria com a criança (a apreensão era devido a longa ausência da criança, o grupo ameaçava matá-lo no seu retorno do hospital, sob alegação de que ele tinha deixado de ser índio). Nós, juntamente com o superintendente Tomás, da FUNAI, por duas vezes, tivemos que realizar um longo diálogo com as três mulheres e o Iawí antes de devolver o pequeno Trumach ao posto.

Com o pequeno Trumach estabilizado no posto, conseguimos parar e replanejar o crescimento da família. Interrogado por nós, quando viria o próximo filho, Iawí nos respondeu: 'Quando Trumach começar a andar, eu fazer outro cunumin'. Isto não nos surpreendeu, pois várias nações Tupi, como os Suruí de Rondônia, só reiniciam as relações sexuais com a esposa, depois que o filho começa a andar (COSTA, 1992, n.p.).

Os abusos tutelares que envolveram o nascimento de Trumak não se encerraram com seu retorno a área. Ali, segundo relatos da época, Trumak teria ficado sob o cuidado permanente de uma enfermeira que, alegadamente, não permitia a aproximação dos pais, a quem julgava "sujos". Quando se viu a sós com seus parentes, Trumak teria sido 
sujeito a várias formas de rejeição. A rejeição se deu, possivelmente, pela não observação dos ritos, prescrições e interdições, próprias dos Tupi-Guarani, que acompanham o nascimento das crianças, o que constitui uma ameaça à vida dos pais e da própria criança.

Antropólogos e indigenistas ainda se ocuparam do planejamento familiar de mais uma criança para os Avá-Canoeiro. Putdjawa nasceu em Gurupi (cidade do estado de Tocantins), para onde foi levada Tuia para receber assistência médica durante o parto. Tuia e Matxa driblaram o cerco dos tutores e realizaram o parto em uma mata. Putdjawa não sofreu as agressões ou a rejeição vivida por Trumak, recebendo não só o tratamento ritual adequado, mas, também, maior atenção e vigilância por parte das demais mulheres da família.

O que sobressai do caso relatado é a espontaneidade com que os brancos atuam sobre os nascimentos das crianças avá-canoeiro sob a sua tutela. A preocupação em assegurar a "reprodução" do povo AváCanoeiro, como se isto fosse possível a partir simplesmente do nascimento biológico de indivíduos, assinala de que modo a representação indigenista dos Avá-Canoeiro como "em vias de extinção" se impõe sobre o relacionamento respeitoso e informado, donde a sobrevivência física da criança é colocada acima de sua existência cultural, como de resto expressa metonimicamente a situação tutelar de seus parentes.

\section{O predicamento da indianidade como obstáculo ao respeito devido aos indígenas no Brasil e no Canadá}

Com vistas a propor uma análise comparada dos eventos acima descritos, deve-se buscar uma interpretação para como e por que semelhantes eventos puderam acontecer do modo como ocorreram. Chama a atenção o modo liminar como os tutores (agentes de saúde, indigenistas, pesquisadores etc.) implicados em cada caso extrapolaram a política para agirem de modo violento sobre os sujeitos indígenas. Pode-se observar a ação tutelar como uma violência no sentido estrito do termo, pois a tutela coercitiva seria esse poder capaz de definir e 
conservar a lei sobre os índios sem estar ela própria subordinada às demais leis da sociedade nacional e às dos próprios indígenas.

A reserva e a terra indígena que circunscrevem as vidas dos Nimpkish e dos Avá-Canoeiro, possibilitando a operacionalização dos regimes de indianidade como campo ideológico orientador das relações interétnicas, parecem compartilhar, nesse sentido, das características dos campos de concentração ou outras instituições totais na medida em que os "índios/Indians" são concebidos como objetos do poder tutelar ou "internos", cabendo aos estados, por meio de corpos administrativos e médicos, implementar as medidas que correspondam aos anseios contraditórios da sociedade dominante de fazer desaparecer ou controlar a ameaça potencial do "outro", seja pela sua morte ou pela sua reprodução dirigida nos termos da sociedade dominante.

Munidos de boas intenções, os tutores exercem a paradoxal tarefa de saber pelos "índios" o que é melhor para eles sem consultá-los. Sob o cinismo das boas intenções, cometem-se as piores violações da autonomia indígena, donde devemos entender que de todas elas é o advento da tutela coercitiva que constitui o abuso mais grave (DYCK, 1996, p. 23).

Toda a assimetria das relações interétnicas decorre daí, de tal modo que é estabelecida entre os tutores/agentes de saúde e os Nimpkish e os Avá-Canoeiro uma série de reclassificações destes, primeiro como "índios/Indians" ou sujeitos em transição de uma cultura selvagem para outra civilizada. Esta reclassificação, todavia, promove, segundo, a redução da autonomia dos indígenas com o propósito de manipulá-los como corpos passivos da ação tutelar.

A tutela rotinizada assegura a operacionalidade de representações pré-concebidas acerca dos "índios", que podem ser elucidadas reciprocamente pela suposta resistência à dor atribuída aos Nimpkish, de um lado, e a suposta vulnerabilidade física atribuída aos AváCanoeiro como "etnia em vias de extinção", de outro. Do mesmo modo, é possível observar como os preconceitos são acionados para supor os Nimpkish mais predispostos a aceitar a morte, o que seria equivalente (mas não igual) à suposição de que os Avá-Canoeiro praticam o aborto indiscriminadamente. Tais preconceitos acerca da indianidade servem para tornar legitimamente violável os corpos e as sexualidades 
indígenas, colocando estes à disposição dos usos e abusos tutelares, nenhum deles considerados crimes porque visam, em última instância, assegurar aos "índios/Indians" os benefícios médicos da cultura ocidental para seu próprio bem.

Com esta análise procura-se demonstrar de que modo os regimes de indianidade reduzem a condição indígena a um conjunto estereotipado de representações de subumanidade que os tornam meros objetos do poder tutelar em detrimento de sua condição humana e autonomia. Como explicar que um dos efeitos desta subordinação classificatória é a produção da representação dos corpos indígenas como matáveis/nascíveis impunemente?

O que os eventos relatados sugerem é que, no contexto tutelar indigenista, as "reservas indígenas", enquanto campos de operacionalização dos regimes de indianidade, oscilam entre a eliminação e a reprodução física e simbólica dos índios. O que explica esta aparente contradição é o fato de que o poder tutelar ou a tutela coercitiva enquanto expressão do poder nacional torna os indígenas capturados em seu raio de ação seres "subumanizados", ao ponto de serem seviciados, violados, mortos, segregados de suas famílias, sem que isto se constitua em crime pelas sociedades nacionais, o que somente é tornado possível pela justificativa propiciada pelo assimilacionismo de que a transitoriedade do ser indígena é a condição de possibilidade para sua ilimitada manipulação e experimentação.

Os dois eventos relatados apresentam situações reais de tutela coercitiva/poder tutelar típicas do paradigma assimilacionista. Ao interpretar comparativamente as práticas tutelares na área da saúde indígena a partir da noção de regimes de indianidade, emerge dos eventos uma tese particular acerca da centralidade de definições de indianidade como categoria operacionalizadora da dominação racional exercida pelos estados com vistas a promover tanto a morte quanto o nascimento indígena em condições desumanizadoras. Desta perspectiva, o horizonte aberto por um novo paradigma multiculturalista é promissor para restituir aos indígenas o direito de autodeterminação e autonomia sobre suas próprias vidas. Entretanto, este novo cenário somente superará o assimilacionismo quando for capaz de suplantar o predicamento da indianidade pelo reconhecimento 
pleno dos indígenas como sujeitos de direito em todas as dimensões da vida humana.

Torna-se difícil acreditar na mudança das definições e preconceitos sobre os indígenas enquanto as instituições indigenistas dos Estados nacionais não passarem por uma profunda reforma descolonizadora. Essa, por sua vez, tem que aprender a relacionar-se com os povos indígenas como sociedades duradouras de seres humanos e não como bandos em transição compostos por seres culturalmente inferiores. Todo o horizonte aberto pelos direitos humanos no plano internacional e a redefinição dos direitos culturais dos povos indígenas enquanto coletividades distintas dos Estados, em especial a partir dos anos 90 do século $\mathrm{XX}$, deveria ensinar aos governos que os indígenas não são sujeitos de direitos porque são povos culturalmente distintos, mas sim que são povos culturalmente distintos porque são humanos. Neste sentido, o multiculturalismo nasceu caduco para superar o regime imposto pelo assimilacionismo.

Para garantir a cidadania efetiva dos povos indígenas no século XXI, necessitamos voltar a falar de projetos democráticos radicais, que sejam inclusivos de uma concepção mais diversa de sociedade, para além da mera heterogeneidade ideológico-partidária; e de um humanismo no plural, onde a relação entre o universalismo individualista das sociedades ocidentais seja efetivamente superado pela aceitação das tradições, culturas e identidades particulares que não as ameaçam, apenas as alargam enquanto mundos onde cabem todos os outros.

\section{Referências bibliográficas}

BLANCHETTE, Thaddeus Gregory. Cidadãos e selvagens: Antropologia e administração indígena nos Estados Unidos, 1870-1890. Rio de Janeiro: e-papers, 2013.

BONFIL BATALLA, Guillermo. Do indigenismo da revolução à antropologia crítica. In: JUNQUEIRA, Carmen; CARVALHO, Edgard (Org.). Antropologia e Indigenismo na América Latina. São Paulo: Cortez, 1981. p. 87-105. 
CARVALHO, José Murilo de. Cidadania: tipos e percursos. Estudos históricos, Rio de Janeiro, v. 9, n. 18, p. 337-360, 1996.

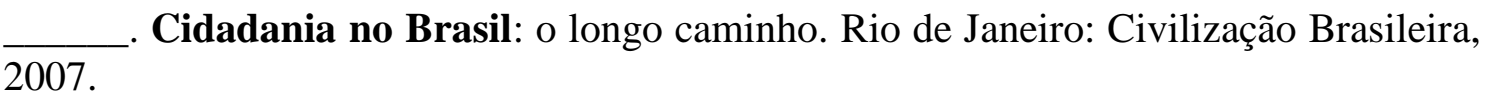

COSTA, Mário Arruda. Relatório. Mimeo. 1992.

CULHANE, Dara. An Error in Judgement: The Politics of Medical Care in an Indian/White Community. Vancouver: Talonbooks, 1987.

DAS, Veena. Critical Events: An Anthropological Perspective on Contemporary India. Oxford: Oxford University Press, 1995.

DIACON, Todd A. Stringing Together a Nation: Cândido Mariano da Silva Rondon and the Construction of a Modern Brazil, 1906-1930. Durham/London: Duke University Press, 2004.

DYCK, Noel. Tutelage and the Politics of Aboriginality: A Canadian Dilemma. Ethnos: Journal of Anthropology, v. 56, p. 1-2, p. 138-154, 1991.

What is the Indian Problem: Tutelage and Resistance in Canadian Indian Administration. St. John's: ISER, 1996 [1991].

Tutelage, resistance and co-optation in Canadian Indian Administration. CRSA/RCSA, v. 34, n. 3, p. 333-348, 1997.

FABIAN, Johannes. Time and the other: How Anthropology Makes its Object. New York: Columbia, 1983.

FOUCAULT, Michel. Soberania e disciplina (1976). In: MACHADO, Roberto (Org.). Microfísica do poder. Rio de Janeiro: Edições Graal, 1995. p. 100-106.

A governamentalidade (1978). In: MACHADO, Roberto (Org.). Microfísica do poder. Rio de Janeiro: Edições Graal, 1995. p. 163-174.

HALE, Charles. Activist Research v. Cultural Critique: Indigenous Land Rights and the Contradictions of Politically Engaged Anthropology. Cultural Anthropology, 2006.

LAVOIE, Michel; VAUGEOIS, Denis. L'Impasse Amérindienne: Trois commissions d'enquête à l'origine d'une politique de tutelle et d'assimilation 1828-1858. Québec: Septentrion, 2010.

MARSHALL, T. H. Cidadania, classe social e status (1950). Zahar: Rio de Janeiro, 1967. 
MAUSS, Marcel. Ofício do Etnógrafo, Método Sociológico (1902). In: CARDOSO DE OLIVEIRA, Roberto (Org.). Mauss. São Paulo: Ática, 1979. p. 53-59. (Coleção Grandes Cientistas Sociais).

RAMOS, Alcida Rita. Indigenism: Ethnic Politics in Brazil. Madison: The University of Wisconsin Press, 1998.

RODRIGUES, Patrícia Mendonça. Os Avá-Canoeiro do Araguaia e o tempo do cativeiro. Anuário Antropológico 2012-I, 2013.

SIMARD, Jean-Jacques. La Réduction: entre l'envers du blanc et l'avenir pour soi. La Réduction: L'Autochtone inventé et les Amérindiens d'aujourd'hui. Québec: Septentrion, 2003.

SOUZA LIMA, Antonio Carlos de. Aos Fetichistas, Ordem e Progresso: um estudo do campo indigenista no seu estado de formação. Rio de Janeiro: Museu Nacional, 1985.

Sobre indigenismo, autoritarismo e nacionalidade: considerações sobre a constituição do discurso e da prática da proteção fraternal no Brasil. In: OLIVEIRA, João Pacheco de (Org.). Sociedades indígenas e indigenismo no Brasil. São Paulo: Marco Zero, 1987. p. 149-204.

Um grande cerco de paz: poder tutelar, indianidade e formação do Estado no Brasil. Petrópolis: Vozes, 1995.

(Org.). Gestar e Gerir: estudos para uma antropologia da administração pública no Brasil. Rio de Janeiro: Relume Dumará, 2002.

TANAKA, Emiko Saldívar. Prácticas cotidianas del Estado: una etnografia del indigenismo. México: Universidad Iberoamericana/Plaza y Valdes Editores, 2008.

TEÓFILO DA SILVA, Cristhian. O regime tutelar na formação do índio: Aspectos da sobrevivência e da sociabilidade dos Avá-Canoeiro sob um programa do indigenismo empresarial. Anuário Antropológico/2009-2, 2010.

Cativando Maíra: A sobrevivência dos índios Avá-Canoeiros no Alto Rio Tocantins. Goiânia: Editora da PUC; São Paulo: Editora Annablume, 2010.

Indigenismo como ideologia e prática de dominação: Apontamentos teóricos para uma etnografia do indigenismo latino-americano em perspectiva comparada. Latin American Research Review, v. 47, n. 1, p. 16-34, 2012.

Povos indígenas, governança indigenista e autonomia política indígena em perspectiva comparada: Elementos para o diálogo interétnico no Brasil e no Canadá. Especiaria, Florianópolis, v. 14, n. 15, p. 13-32, 2015. 
TEOFILO DA SILVA, Cristhian; LORENZONI, Patricia. A moldura positivista do indigenismo: A propósito do Estatuto do Índio para a proteção de povos indígenas no Brasil. In: TRINCHERO, Hugo; MUÑOZ, Luis Campos; VALVERDE, Sebastián. (Org.). Pueblos indígenas, Estados nacionales y fronteras: Tensiones y paradojas de los procesos de transición contemporáneos en América Latina. Buenos Aires: CLACSO/Editorial de la Facultad de Filosofia y Letras-UBA/Universidad Academia Humanismo Cristiano, 2014.

TEOFILO DA SILVA, Cristhian; HÉBERT, Martin. Regards sur les études autochtones comparées. Recherches Amérindiennes au Québec, v. 44, n. 2-3, p. 3-4, 2014.

UPTON, L. F. S. The Origins of Canadian Indian Policy. Journal of Canadian Studies, v. 8, n. 4, p. 51-60, 1973.

VITENTI, Livia. Le pouvoir tutélaire et la lutte pour la souveraineté des peuples autochtones du Brésil. Anthropologie et Sociétés, v. 32, 2008.

WEAVER, Sally. Making Canadian Indian Policy: The Hidden Agenda 1968-1970. Toronto: University of Toronto Press, 1981.

Recebido em: 11/09/2016 * Aprovado em: 20/11/2016 * Publicado em: 31/12/2016 